\title{
Characteristics of White Soybean Chungkookjang Fermented by Bacillus subtilis D7
}

Na-Ri Lee', Sung-Bo Park', Sang-Mee Lee', Tae-Hun Go', Dae-Youn Hwang', Dong-Seob Kim', Seong-Yun Jeong ${ }^{2}$ and Hong-Joo Son *

${ }^{1}$ College of Natural Resources and Life Science, Pusan National University, Miryang 627-706, Korea

${ }^{2}$ Department of Medical Life Science, Catholic University of Daegu, Daegu 712-784, Korea

Received November 27, 2012 /Revised March 26, 2013 / Accepted March 27, 2013

\begin{abstract}
This study was carried out to investigate the characteristics of white soybean Chungkookjang fermented by Bacillus subtilis D7. The highest germination rate was obtained under $25^{\circ} \mathrm{C}$ when water was supplied for 4 days at intervals of $2 \mathrm{hr}$. The total isoflavone content was $971.3 \mu \mathrm{g} / \mathrm{g}$ before germination and $1023.8 \mathrm{\mu g} / \mathrm{g}$ after germination. The amino type- and ammonia type-nitrogen contents of Chungkookjang were proportional to the fermentation time. The $\mathrm{pH}$ values of all Chungkookjang soybeans increased up to $\mathrm{pH} 7.8-8.0$ during fermentation. The number of viable cells in all Chungkookjang soybeans increased significantly up to $24 \mathrm{hr}$. The protease activity of all Chungkookjang soybeans increased up to 30-36 hr. The a- and $\beta$-amylase activities of Chungkookjang fermented by B. subtilis D7 were enhanced with increasing fermentation time. Analysis of the effect of Chungkookjang intake on the liver function of mouse showed that the alkaline phosphatase (ALP) activity and the superoxide dismutase (SOD) activity in the Chungkookjang diet group were markedly higher than those in the control group. The asparatate aminotransferase (AST) activity in the germinated soybean Chungkookjang diet group was higher than that in the nongerminated soybean Chungkookjang diet group. Therefore, Chungkookjang soybeans fermented with B. subtilis D7 can be expected to have an increased content of functional components and improved quality characteristics.
\end{abstract}

Key words : Chungkookjang, Bacillus subtilis, fermentation, functional food

\section{서 론}

최근, 의학과 식품과학의 발전에 따른 식생활 개선 등으로 콩의 영양성 및 기능성에 대한 많은 연구가 전 세계적으로 활발하게 이루어지고 있다. 콩에는 단백질, 탄수화물, 지방의 필수 3 대 영양소와 함께 각종 무기질 및 비타민이 풍부하게 함유되어 있다. 특히, 콩은 타 식품에 비하여 비타민 $\mathrm{B}_{1}$ 과 비타 민 $\mathrm{E}$ 를 많이 함유하고 있으며, 이외 이소플라본, 사포닌, 피틴 산, 트립신 저해제 등의 다양한 생리활성물질이 함유되어 있 어 심혈관 질환과 골다공증 예방, 항암 작용 등이 있는 것으로 밝혀졌다 $[5,16]$. 이와 같은 특성으로 인하여 콩은 우리나라 전통 발효식품의 주된 원료 및 중요한 식물 유래 기능성 소재 로서 다양하게 이용되어왔다[10].

콩은 발아가 진행됨에 따라 호흡과 대사작용으로 기능성물질 을 포함한 다양한 영양분 및 생리활성물질의 화학적 변화가 일어 난다. $\operatorname{Kim}$ 등[13]은 명조건 하에서 발아된 콩으로 청국장을 제조

\section{*Corresponding author}

Tel : +82-55-350-5544, Fax : +82-55-350-5549

E-mail : shjoo@pusan.ac.kr

This is an Open-Access article distributed under the terms of the Creative Commons Attribution Non-Commercial License (http://creativecommons.org/licenses/by-nc/3.0) which permits unrestricted non-commercial use, distribution, and reproduction in any medium, provided the original work is properly cited.
하여 발효특성을 확인한 바 있으며, Jung 등[8]은 대두의 발아시 간 별로 제조한 발아대두 청국장의 품질특성을 규명한 바 있다.

항암효과, 혈압강하효과, 혈청 콜레스테롤 저하, 고혈압 및 동맥경화 예방, 골다공증 예방, 혈전용해능 등 청국장의 효능 이 밝혀지면서 그 소비가 급격히 증가하고 있는데 [4, 17, 32], 이러한 기능은 콩과 볏짚에 서식하는 다양한 Bacillus 균주들 의 발효작용에 의하여 보다 강화되는 것으로 밝혀졌다[14]. Bacillus 균주는 짧은 발효기간 중에 엄청난 숫자로 증식되는 데 이때, 각종 콩 단백질이 분해되면서 원래 콩에는 없거나 그 양이 적던 항암, 항산화, 면역물질과 같은 생리활성물질이 새로 생겨나거나 강화된다[19].

그러나 이러한 많은 기능과 연구가 있음에도 불구하고 청국 장 제조는 아직까지 재래식 방법을 이용하여 제조되고 있는 것이 현실이다. 재래식 청국장은 볏짚을 증자대두에 접종하여 제조되고 있는데, 이러한 방법은 비위생적이고 균일한 품질을 가진 청국장을 제조할 수 없다는 단점이 있다[15]. 청국장은 제조방법, 사용원료 및 사용 종균에 따라 맛, 기능성의 차이가 있기 때문에 청국장의 품질에 큰 영향을 미치는 요인이 되고 있다[7]. 그러므로 청국장 산업의 활성화를 위해서는 제조법의 표준화와 품질 균일화가 선행되어야 할 것이다.

본 연구에서는 미발아 콩에 비하여 발아시킨 콩에는 이전에 존재하던 성분이 대폭 강화된다는 사실과 지금까지 판매되고 있는 대부분의 청국장은 볏짚을 이용하여 제조되고 있기 때문 
에 품질의 일관성이 없다는 사실에 착안하여 콩의 최적 발아 조건, 순수분리된 종균을 이용한 청국장 발효조건 확립 및 최 종 생산된 청국장의 마우스 간세포의 항산화 효소 활성과 혈 청의 각종 효소활성에 대한 효과를 검토하였다.

\section{재료 및 방법}

\section{사용균주 및 대두}

본 연구에 사용된 균주는 한국의 전통식품인 된장으로부터 분리 및 동정된 Bacillus subtilis D7 [20]이었다. 청국장 제조에 사용된 콩은 재배농가에서 직접 구입한 흰콩(백태, Glycine $\max \mathrm{L}$. Merr)이었다.

대두 발아조건 및 발아 전후 이소플라본 함량 비교

백태 $150 \mathrm{~g}$ 을 각각 1 7시간 동안 증류수에 수침시킨 후, 2 6시간마다 물을 공급하면서 발아를 유도하였다. 이때 온도 는 20 30 ${ }^{\circ} \mathrm{C}$ 로 각각 조정하였다. 발아율은 다음 식에 의하여 산출하였다.

$$
\text { 발아율 }(\%)=(\text { 발아콩의 수/전체 콩의 수 }) \times 100
$$

발아 전후 콩의 이소플라본 함량은 HPLC를 사용하여 Wang 등[30]의 방법을 일부 변경한 gradient solvent system 으로 분석하였다. 동결건조하여 분쇄한 시료 $1 \mathrm{~g}$ 에 $0.1 \mathrm{~N}$ $\mathrm{HCl} 2 \mathrm{ml}$ 및 acetonitrile $10 \mathrm{ml}$ 을 첨가하여 3시간 동안 진탕 하였다. Whatman no. 4 여과지로 여과한 후, 여액을 진공농축 하였다. 농축 시료를 $80 \%$ methanol에 용해시킨 후, $0.45 \mu \mathrm{m}$ membrane filter로 여과하여 HPLC 분석을 위한 시료로 사 용하였다. 사용된 컬럼은 $\mu$-Bondapak C18 컬럼이었고, UV detector를 이용하여 $254 \mathrm{~nm}$ 에서 분석하였다. 이동상은 시작 시 $20 \%$ methanol 100 에서 50 분 후 $60 \%$ methanol 100 이 되 도록 하였고, 유속은 $1 \mathrm{ml} / \mathrm{min}$ 이었다. 이소플라본 함량은 표준물질의 농도에 대한 피크의 면적을 표준정량곡선으로부 터 계산하였다.

\section{청국장 발효}

B. subtilis $\mathrm{D} 7$ 을 Luria-Bertani 배지에서 $30^{\circ} \mathrm{C}, 200 \mathrm{rpm}$ 으로 20 시간 동안 배양한 후, 발효를 위한 종균으로 이용하였다. 발아된 백태를 $121^{\circ} \mathrm{C}$ 에서 30 분간 증자한 후, 종균 배양액을 $1 \%(\mathrm{v} / \mathrm{w})$ 접종하여 $40^{\circ} \mathrm{C}$ 에서 48 시간 동안 발효시켜 청국장 을 제조하였다(종균-발아콩). 청국장에 6 배 부피의 증류수를 첨가하여 분쇄 및 원심분리한 후, 상등액을 각종 발효지표 분 석에 사용하였다. 이때, 미발아콩에 B. subtilis $\mathrm{D} 7$ 을 접종한 것(종균-미발아콩)과 미발아콩에 볏짚 끓인 물을 접종한 것(볏 짚-미발아콩)을 대조구로 이용하였다.

\section{발효지표 분석}

환원당은 dinitrosalicylic acid (DNS)법[22]으로 측정하였
으며, glucose를 표준물질로 사용하였다. 아미노태 질소 함량 은 formol 적정법[1], 암모니아태 질소 함량은 indophenol blue법[1]을 사용하여 측정하였다. $\mathrm{pH}$ 측정은 $\mathrm{pH}$ meter를 이 용하여 측정하였다.

Protease 활성은 상기에서 조제된 상등액을 조효소액으로 사용하여 측정하였다. 기질용액 $(0.6 \%$ hammerstern casein, $\mathrm{pH}$ 7.2) $1 \mathrm{ml}$ 와 조효소액 $1 \mathrm{ml}$ 를 시험관에 넣고 $30^{\circ} \mathrm{C}, 10$ 분간 반응시켰다. $0.4 \mathrm{M}$ trichloroacetic acid (TCA) 용액 $1 \mathrm{ml}$ 를 가 하여 반응을 중지시킨 후, 원심분리에 의하여 상등액을 회수 하여 UV/VIS spectrophotometer를 이용하여 $280 \mathrm{~nm}$ 에서 흡 광도를 측정하였다[27]. 효소 1 unit는 상기 조건에서 분당 0.01 의 흡광도 증가를 나타내는 효소량으로 정의하였다.

Amylase 활성은 $a$-amylase와 $\beta$-amylase로 구분하여 측정 하였다. a-Amylase 활성은 다음과 같이 측정하였다[27]. $0.5 \%$ soluble starch 용액( $0.4 \mathrm{M}$ acetate buffer, $\mathrm{pH}$ 4.8) $2 \mathrm{ml}$ 와 조효 소액 $1 \mathrm{ml}$ 를 혼합하여 $30^{\circ} \mathrm{C}$ 에서 10 분간 반응시켰다. $0.4 \mathrm{M}$ $\mathrm{TCA} 1 \mathrm{ml}$ 를 첨가하여 반응을 중지시킨 후, 원심분리에 의하 여 회수한 상등액 $1 \mathrm{ml}$ 에 $\left[0.005 \% \mathrm{I}_{2}\right.$ 및 $\left.0.05 \% \mathrm{KI}\right]$ 용액 10 $\mathrm{ml}$ 을 첨가하여 $600 \mathrm{~nm}$ 에서 흡광도를 측정하였다. 효소 1 unit 는 상기 조건에서 blank 흡광도가 $10 \%$ 감소되는 효소량으로 정의하였다. $\beta$-Amylase 활성 측정은 상등액을 DNS법으로 maltose의 양을 측정한 것만 제외하고 a-amylase 측정법과 동 일하였다[23]. 이때 표준곡선은 maltose를 이용하여 작성하였 다. 효소 1 unit는 상기 조건에서 $1 \mathrm{mg}$ 의 maltose를 유리시킬 때의 효소량으로 정의하였다.

생균수는 발효 중인 콩 $1 \mathrm{~g}$ 을 멸균수 $9 \mathrm{ml}$ 에 첨가하여 계단 희석한 후, 표준평판법에 의하여 배양하여 계수하였다.

\section{동물실험}

동물실험을 위한 청국장 추출물은 다음과 같이 조제하였 다. 동결 건조된 청국장 $20 \mathrm{~g}$ 을 증류수 $200 \mathrm{ml}$ 에 첨가하여 200 $\mathrm{rpm}$ 에서 2 시간 동안 진탕한 후, 원심분리(1,000 rpm, 20 분)에 의하여 잔여물을 제거하고, 상등액을 회수하여 동결건조 함으 로써 청국장 추출물을 조제하였다. 이하 실험은 부산대학교 동물실험윤리위원회로부터 과학성과 윤리성에 대한 심사를 거쳐 승인을 받아 수행하였다. 실험에 사용된 동물은 8 주령의 ICR 마우스로서 샘타코(오산, 한국)로부터 구입하였다. ICR 마우스는 방사선 조사된 사료(Purina Mills Inc)를 자유 급식 하였으며, 12시간의 조명주기로 specified pathogen-free 상태 의 부산대학교 청정실험동물센터(온도 $23 \pm 2{ }^{\circ} \mathrm{C}$, 상대습도 $50 \pm 5 \%$ )에서 사육하였다. ICR 마우스를 4 개 그룹으로 구분하 여 그룹당 5 마리의 실험동물을 임의적으로 배정하였으며, 증 류수 음용군(대조군), 종균-발아콩 청국장 음용군, 종균-미발 아콩 청국장 음용군, 볏짚-미발아콩 청국장 음용군으로 나누 어 실험하였다. 청국장 추출물 시료는 증류수에 $70 \mathrm{mg} / \mathrm{ml}$ 의 농도로 희석한 후, 존데를 이용하여 1 일 1회 투여하였다. 7일 
후에 $\mathrm{CO}_{2}$ 가스를 이용하여 마우스를 안락사 시킨 후, 부검을 실시하였다.

간세포 내 항산화 효소 SOD (superoxide dismutase) 활성 측정은 microplate WST-1 assay [34]를 사용하여 분석하였다. 실험동물에서 적출한 간 $100 \mathrm{mg}$ 을 sucrose buffer $600 \mu \mathrm{l}$ 에 넣고 잘게 자른 뒤, homogenizer를 이용하여 마쇄하였다. 실 온에 30 분간 방치한 후, 튜브에 넣고 $4^{\circ} \mathrm{C}, 5000 \mathrm{rpm}, 10$ 분간 원심분리를 실시해서 상등액만 새 튜브에 $100 \mu \mathrm{l}$ 씩 넣었다. 이렇게 조제된 시료에 WST working solution, enzyme working solution, $\mathrm{ddH}_{2} \mathrm{O}$, dilution buffer를 넣고 $37^{\circ} \mathrm{C}$ 에서 20 분간 배양한 후에 microplate reader를 사용해서 $450 \mathrm{~nm}$ 에서의 흡 광도를 측정했다.

청국장 추출물 섭취가 혈청 내 유전자의 발현에 영향을 미 치는 것을 최소화하기 위하여 약 24 시간 동안 절식하여 $\mathrm{CO}_{2}$ 가스를 이용하여 마우스를 안락사 시킨 후, 혈액을 채취하였 다. 분리된 혈액은 상온에서 30 분 동안 방치한 후, 원심분리하 여 혈청을 회수하였다. 혈청 내 효소의 변화는 혈청분석기 (HITACHI 7080 Automatic Analyzer, Japan)를 이용하여 ALP (alkaline phosphatase)는 Tietz의 방법[30], AST (asparatate aminotransferase) 및 ALT (alanine aminotransferase)는 Reitman과 Frankel의 방법[25]으로 분석하였다.

\section{통계처리}

다른 언급이 없는 한, 모든 실험은 3 반복 수행하였으며, 결 과는 mean $\pm \mathrm{SD}$ 로 제시하였고, 평균치간의 유의성은 SPSS (Statistical Package for Social Sciences) system software package (version 21)을 이용하여 ANOVA 분석(Turkey method)을 하였다.

\section{결과 및 고찰}

\section{대두의 발아 및 이소플라본 함량}

백태를 3 6 시간 동안 침지한 후, 4 일 동안 2 시간마다 물을 공급했을 때, 발아율이 가장 높았다. 또한 이 조건에서 온도별 로 발아율을 조사한 결과, $20^{\circ} \mathrm{C}$ 에서 $78 \pm 2 \%, 25^{\circ} \mathrm{C}$ 에서 $85 \pm 3 \%$, $30^{\circ} \mathrm{C}$ 에서 $64 \pm 1 \%$ 로서 $25^{\circ} \mathrm{C}$ 에서 발아율이 가장 높았다(미제 시). 이상의 결과로 콩의 발아온도는 $20^{\circ} \mathrm{C}$ 나 $30^{\circ} \mathrm{C}$ 보다 $25^{\circ} \mathrm{C}$ 에 서 수행하는 것이 적당한 것으로 판단되었다. 그러나 Park 등 [24]은 콩의 발아온도가 각각 $10^{\circ} \mathrm{C}, 18^{\circ} \mathrm{C}, 25^{\circ} \mathrm{C}$ 및 $35^{\circ} \mathrm{C}$ 일 때 48 시간째에 $2 \%, 95 \%, 75 \%, 68 \%$ 의 발아율을 나타내었고, $25^{\circ} \mathrm{C}$ 보다 $18^{\circ} \mathrm{C}$ 에서 높은 발아율을 보였다고 보고하여 본 결과와
상이하였다. 한편, 발아 전후의 이소플라본 함량을 조사한 결 과, 각각 $971.3 \mu \mathrm{g} / \mathrm{g}$ 과 $1023.8 \mu \mathrm{g} / \mathrm{g}$ 으로서 발아 전보다 발아 후 총 이소플라본 함량이 증가하였다(Table 1). 대두가 발아되 면 이소플라본의 함량이 증가하며, 특히 발아 싹의 길이가 증 가할수록 이소플라본의 함량은 증가하는 것으로 알려져 있다. 이소플라본은 체내 이용률이 비교적 낮은 배당체인 genistin, daidzin, glycitin 등과 체내 이용률이 비교적 높은 비배당체인 genistein, daidzein, glycitein 등의 형태로 존재하는데, 대두를 발효시키면 대부분의 이소플라본은 비배당체로 전환되며 콜 레스테롤 수치를 감소시키는 등 생리활성이 증가되는 것으로 보고되어 있다[12]. 따라서 청국장 발효에 따른 비배당체 함량 의 변화를 상세하게 조사할 필요가 있음을 알 수 있었다.

\section{청국장의 성분분석}

당류는 청국장 발효과정 중에 Bacillus 등이 세포 밖으로 분 비하는 효소의 작용으로 콩 전분이 분해됨으로써 생성되며, 청국장 단맛 성분의 주체 물질이다. 따라서 발효시간 경과에 따른 청국장의 환원당 함량을 측정한 결과, 종균-발아콩의 경 우 발효 24시간에 $18.3 \mathrm{mg} / \mathrm{g}$ 로 최고함량을 보이다가 그 이후 감소하였고, 종균-미발아콩은 발효 12 시간에 $16.6 \mathrm{mg} / \mathrm{g}$ 로 최 고 함량을 보이다가 그 이후 감소하는 경향을 보였다(Fig. 1). 볏짚-미발아콩의 경우, B. subtilis D7을 접종한 경우보다 낮은 당 함량을 나타내었으며, 반복적인 증감현상이 나타났다. 모 든 청국장에서 발효 24 시간 내에 환원당 함량이 증가하는

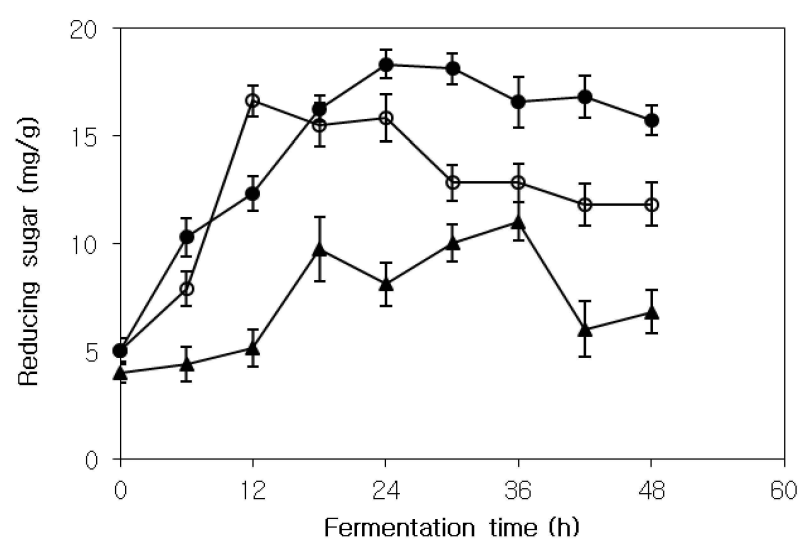

Fig. 1. Changes of reducing sugar during Chungkookjang fermentation. •, Chungkookjang fermented by B. subtilis using germinated soybean; $O$, Chungkookjang fermented by B. subtilis using non-germinated soybean; $\boldsymbol{\Delta}$, Chungkookjang fermented by rice straw using non-germinated soybean.

Table 1. Isoflavone contents of germinated, and non-germinated soybeans

\begin{tabular}{cccccccc}
\hline \multicolumn{3}{c}{ Non-germinated soybean $(\mu \mathrm{g} / \mathrm{g})$} & \multicolumn{5}{c}{ Germinated soybean $(\mu \mathrm{g} / \mathrm{g})$} \\
\hline Daidzin & Glacitin & Genistin & Total & Daidzin & Glacitin & Genistin & Total \\
\hline 435.0 & 84.9 & 451.4 & 971.3 & 498.6 & 131.5 & 393.7 & 1023.8 \\
\hline
\end{tabular}


이유는 미생물 생육에 따른 amylase의 작용에 의한 것으로 추정된다. 특히 다음에 제시된 $\beta$-amylase 활성의 변화 패턴과 환원당 함량 변화 패턴이 비슷한 것으로 보아 상관관계가 있 는 것으로 판단되며, 이러한 현상은 $\mathrm{Oh}$ 등[23]의 보고와 유사 하였다.

콩 발효식품의 감칠맛의 척도인 아미노태 질소는 콩 단백질 이 분해되어 생성되는 물질로서, 장류 발효의 품질 지표로서 중요하다. 우리나라의 식품공전에 의하면 청국장의 아미노태 질소 함량은 $280 \mathrm{mg} \%$ 이상으로 규정하고 있다. 모든 실험 조건에서 아미노태 질소 함량은 발효시간 경과에 비례하여 증가하였다(Fig. 2). 종균-발아콩과 종균-미발아콩은 발효 48 시간 만에 각각 $365 \mathrm{mg} \%, 255 \mathrm{mg} \%$ 의 아미노태 질소 함량을 보여주었다. 전체적으로 발아콩을 이용한 경우와 미발아콩을 이용한 경우의 아미노태 생성 패턴은 비슷하였으나 발아콩을 이용한 경우가 함량이 높았다. 볏짚-미발아콩의 경우, 18 245 $\mathrm{mg} \%$ 의 범위에 있어 종균-발아콩보다 낮은 값을 나타내었으 나 종균-미발아콩과는 비슷한 값을 나타내었다. 종균-미발아 콩과 볏짚-미발아콩의 경우, 아미노태 질소의 함량이 각각 255 $\mathrm{mg} \%, 245 \mathrm{mg} \%$ 로서 식품공전 규격인 $280 \mathrm{mg} \%$ 보다 적었다. Youn 등[33]은 발효 45시간 이후에 B. subtilis와 B. natto를 접 종한 시료에서 각각 $422 \mathrm{mg} \%, 356 \mathrm{mg} \%$ 의 아미노태 질소 함 량을 나타내었으며, B. licheniformis를 접종한 시료는 $264 \mathrm{mg} \%$ 의 함량을 나타내었다고 보고하였다.

단백질이 분해되는 과정 중 탈아민 반응에 의하여 생성된 암모니아태 질소가 식품 내에 과량으로 축적되면 부패취로 작용하므로 일반적으로 장류 제품의 이상발효 지표로 사용된 다. 청국장 발효 중 암모니아태 질소의 함량은 모든 실험구에 서 비슷한 생성 패턴을 보여주었으나 발생량에 있어서는 차이 가 있었다(Fig. 3). 발효 42 시간에 종균-발아콩과 종균-미발아

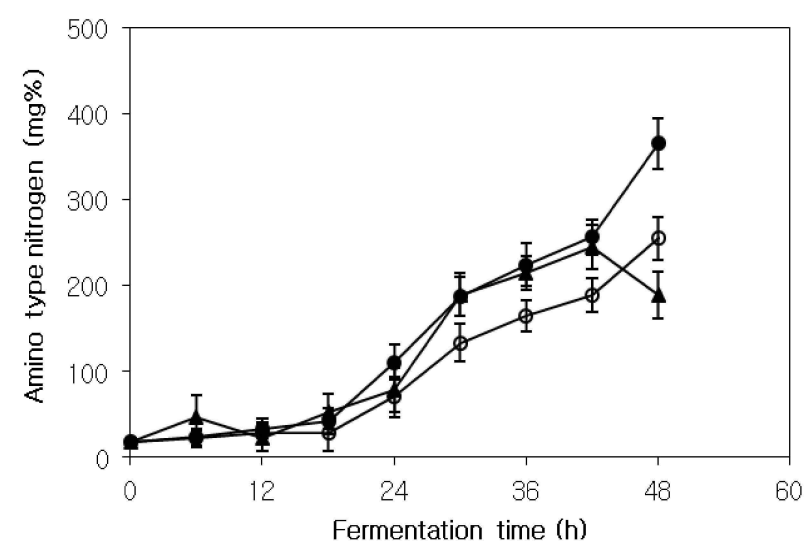

Fig. 2. Changes of amino type nitrogen during Chungkookjang fermentation. @, Chungkookjang fermented by B. subtilis using germinated soybean; $\bigcirc$, Chungkookjang fermented by B. subtilis using non-germinated soybean; $\mathbf{\Lambda}$, Chungkookjang fermented by rice straw using non-germinated soybean.
콩의 경우, 각각 $276 \mathrm{mg} \%, 211 \mathrm{mg} \%$ 를 나타내어 발아콩을 이용한 경우보다 미발아콩을 이용한 경우 암모니아태 질소의 생성이 적었다. 볏짚-미발아콩의 경우, $5 ~ 144 \mathrm{mg} \%$ 의 범위에 있었는데, 이것은 B. subtilis를 접종한 경우보다 낮은 값이었 다. 암모니아태 질소 함량만 고려할 때, 청국장 발효는 24 36 시간 정도 진행시키는 것이 불쾌취가 없는 청국장 제조에 유 리할 것으로 판단된다. Shon 등[26]에 의하면 발효시간이 경 과함에 따라 암모니아태 질소함량이 증가하여 24시간 이후 급격한 증가를 보였다. Eum 등[3]은 발효 48시간에 미발아 볏짚청국장의 경우 $161.56 \mathrm{mg}$ \%를 나타내었으며, 세균을 이용 한 청국장은 볏짚을 이용한 청국장에 비해 훨씬 많은 암모니 아태 질소 함량을 나타내었다고 보고하여 본 실험결과와 유사 하였다.

발효시간에 따른 $\mathrm{pH}$ 의 변화를 관찰한 결과, 발효 초기에는 중성 영 역을 나타내다가 발효시간 경과에 따라 알칼리영역으 로 전환됨을 알 수 있었다(Fig. 4). 청국장의 $\mathrm{pH}$ 가 알칼리로 전환되는 것은 단백질 분해에 기인한 결과인 것으로 판단된 다. 종균-발아콩의 경우 $\mathrm{pH} 6.8$ 8.0, 종균-미발아콩의 경우 $\mathrm{pH}$ 6.7 7.8, 볏짚-미발아콩의 경우 $\mathrm{pH}$ 6.7 8.0의 범위를 나타내어 발효에 따른 큰 차이를 보이지 않았다. Sung 등[29]은 청국장 의 $\mathrm{pH}$ 가 6.6 8.0의 중성 및 알칼리 영역의 $\mathrm{pH}$ 를 보인다고 보 고하여 본 실험결과와 유사하였다. 한편, Youn 등[33]은 증자 한 대두에 Bacillus 속 균주를 접종했을 때 발효초기에는 $\mathrm{pH}$ 6.13 6.21를 유지하다가 발효 후기에는 $\mathrm{pH}$ 8을 넘었다고 보고 하였다. Choi 등[2]은 발효 60 시간 후에 청국장의 $\mathrm{pH}$ 는 6.54에 서 8.49로 증가하였고, Suh 등[29]은 증자한 대두에 B. subtilis 를 접종하여 $40^{\circ} \mathrm{C}$ 에서 72 시간 발효시킨 청국장의 $\mathrm{pH}$ 는 7.25 8.26의 범위를 나타내었다고 하였으며, 그 원인은 발효시 생성되는 암모니아 등의 가스 때문인 것으로 추정하였다. 본

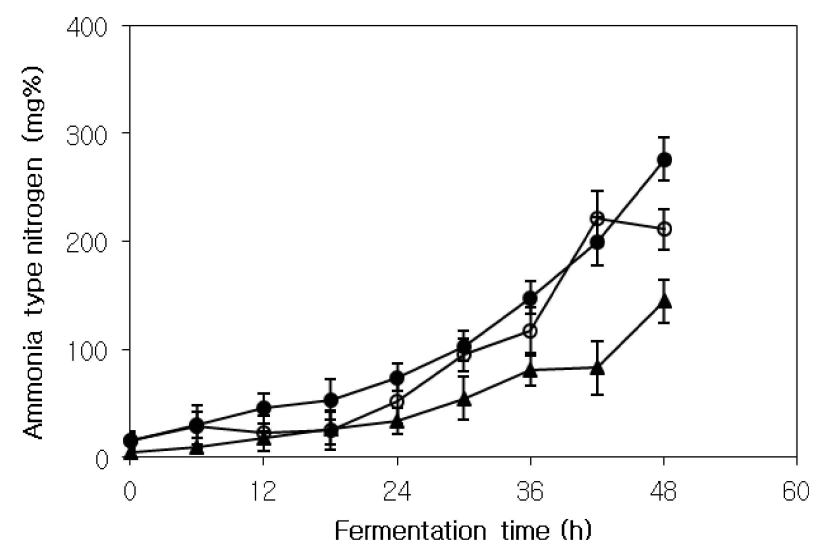

Fig. 3. Changes of ammonia type nitrogen during Chungkookjang fermentation. •, Chungkookjang fermented by B. subtilis using germinated soybean; $O$, Chungkookjang fermented by B. subtilis using non-germinated soybean; $\boldsymbol{\Delta}$, Chungkookjang fermented by rice straw using non-germinated soybean. 
실험의 결과 또한 $\mathrm{pH}$ 와 암모니아태 질소의 패턴이 유사한 것 으로 나타났다.

발효시간에 따른 생균수의 변화를 관찰한 결과, 발효시간이 경과하면서 생균수도 증가함을 알 수 있었다(Fig. 5). 종균-발 아콩의 경우 $0.5 \log \mathrm{CFU} / \mathrm{g}$ 에서 $8.94 \log \mathrm{CFU} / \mathrm{g}$ 로 증가하였 으며, 종균-미발아 콩의 경우 0.6 9.45 $\log \mathrm{CFU} / \mathrm{g}$, 볏짚-미발 아콩의 경우 $0.55 \sim 6.89 \log \mathrm{CFU} / \mathrm{g}$ 의 범위에 있었다. 발아콩과 미발아콩의 경우 비슷한 생균수를 나타내었고, 볏짚을 이용한 경우는 B. subtilis $\mathrm{D} 7$ 을 이용한 경우보다 낮은 생균수를 나타 내었다. Oh 등[23]은 발효 21시간 이후에 청국장에서 8 9 log $\mathrm{CFU} / \mathrm{g}$ 수준의 생균수가 나타났다고 보고하였고, Youn 등 [33]은 B. subtilis를 접종한 경우 발효 35시간 이후에 청국장에 서 $9 \log \mathrm{CFU} / \mathrm{g}$ 까지 증식한다고 하여 본 실험결과와 유사하

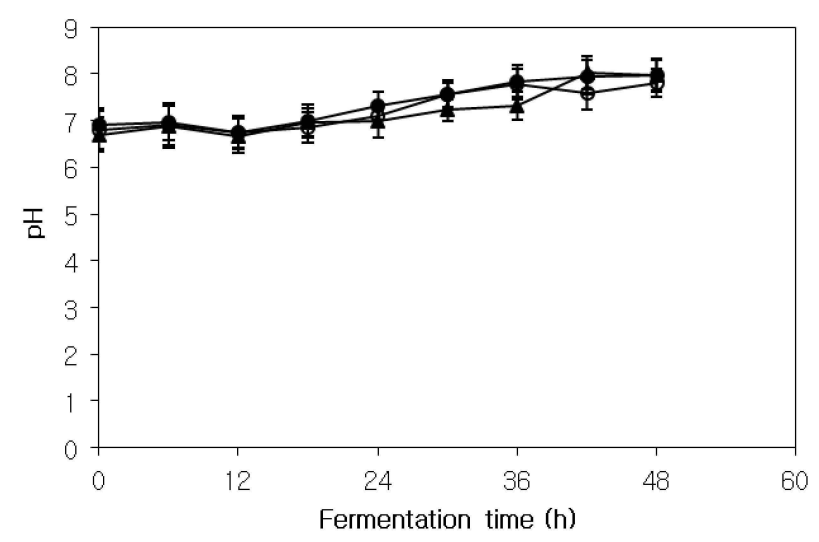

Fig. 4. Changes of $\mathrm{pH}$ during Chungkookjang fermentation. Chungkookjang fermented by $B$. subtilis using germinated soybean; $\bigcirc$, Chungkookjang fermented by $B$. subtilis using non-germinated soybean; $\boldsymbol{\Delta}$, Chungkookjang fermented by rice straw using non-germinated soybean.

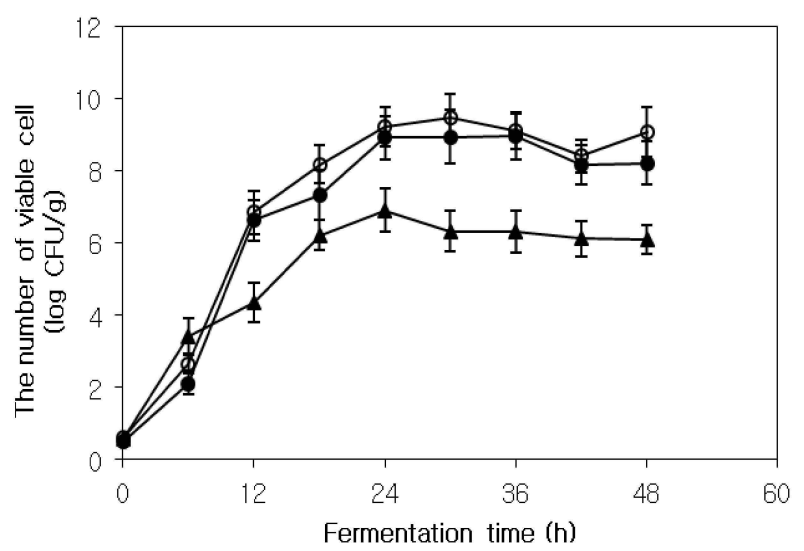

Fig. 5. Changes of viable cell number during Chungkookjang fermentation. •, Chungkookjang fermented by B. subtilis using germinated soybean; $\bigcirc$, Chungkookjang fermented by $B$. subtilis using non-germinated soybean; $\mathbf{\Delta}$, Chungkookjang fermented by rice straw using non-germinated soybean.
였다.

Protease는 콩 단백질을 분해하여 감칠맛 성분인 아미노산 과 polypeptide 등을 생성하므로 청국장의 맛을 결정짓는 중 요한 인자 중의 하나이다. 따라서 청국장의 protease 활성을 조사한 결과, 효소 활성은 발효 6 12 시간 이후부터 증가하여 30 36 시간에 최대값에 도달하였으며, 각 실험구의 protease 활성은 조건에 따라 상당한 차이를 나타내었다(Fig. 6). 종균발아콩의 경우, 발효 30 시간에 $948 \mathrm{U} / \mathrm{g}$ 을 나타낸 이후 비교적 일정하게 유지되었으며, 종균-미발아콩의 경우 30 758 U/g, 볏짚-미발아콩을 이용한 경우 35 490 U/g의 범위에 있어 발 아콩을 이용한 경우 protease 활성이 가장 높았다. 기존에 보 고된 연구에서 사용한 균주, 기질용액, 반응조건 및 효소활성 단위의 정의 등이 상이하여 객관적인 비교는 어렵겠지만 BA86-1 균주를 이용하여 청국장 발효를 수행했을 때 protease 활성은 발효 36시간까지 증가하였다가 그 이후에는 완만하게 감소하였고, BS3-25 균주를 이용한 경우 발효 24시간까지 증가 하였다가 그 이후에는 일정한 패턴으로 나타났다는 Jeong 등 [6]의 보고와 본 실험 결과는 유사하였다.

청국장 발효는 단백질뿐만 아니라 전분의 분해속도도 중요 한 인자인 것으로 알려져 있다. a-amylase 활성의 경우, 종균발아콩은 발효 6시간에 $45 \mathrm{U} / \mathrm{g}$ 에서 30시간에 $51 \mathrm{U} / \mathrm{g}$ 로 증가 한 이후 완만하게 감소하였고, 종균-미발아콩은 31 51 U/g의 범위에 있었다(Fig. 7A). 볏짚-미발아콩 경우, 32 43 U/g의 범 위에 있어 B. subtilis $\mathrm{D}$ 을 이용한 경우보다 낮은 효소활성을 나타내었다. Jeong 등[6]은 청국장의 a-amylase 활성은 48시간 동안 $67 \mathrm{U} / \mathrm{g}$ 로 증가하였다고 보고하였으며, $\mathrm{Oh}$ 등[23]은 $B$. natto와 볏짚을 접종한 청국장에서 a-amylase 활성은 10 12 $\mathrm{U} / \mathrm{g}$ 이었다고 보고하였다. $\beta$-amylase 활성은 모든 실험구에 있어 발효가 진행됨에 따라 증가하였다가 감소하는 패턴을

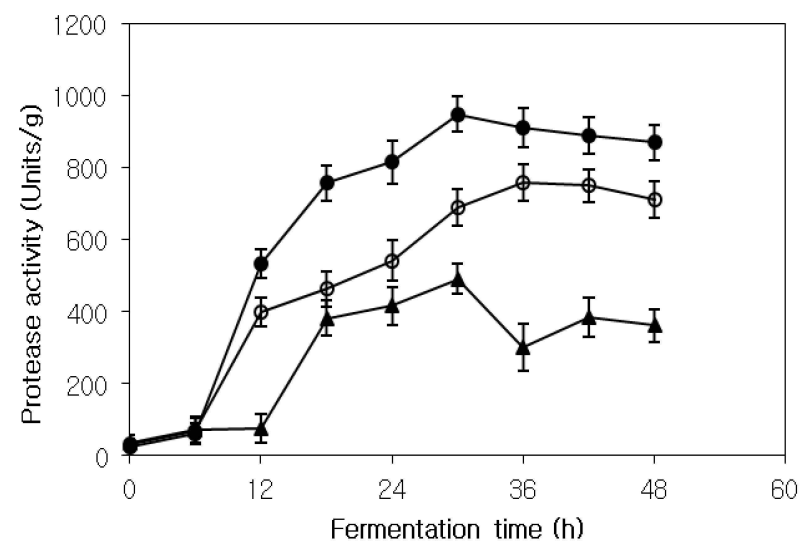

Fig. 6. Changes of protease activity during Chungkookjang fermentation. •, Chungkookjang fermented by B. subtilis using germinated soybean; $O$, Chungkookjang fermented by $B$. subtilis using non-germinated soybean; $\boldsymbol{\Delta}$, Chungkookjang fermented by rice straw using non-germinated soybean. 
Table 2. Effect of feeding of Chungkookjang extract on SOD, ALP, AST and ALT activity in mouse serum and liver cell

\begin{tabular}{lcccc}
\hline & SOD activity $(\%)$ & ALP activity $(\%)$ & AST activity (\%) & ALT activity $(\%)$ \\
\hline Control & $71 \pm 2.7$ & $92 \pm 6.9$ & $93 \pm 5.8$ & $29 \pm 2.1$ \\
Germinated soybean & $100 \pm 1.4^{* * *}$ & $66 \pm 4.1^{* * * *}$ & $80 \pm 5.1^{*}$ & $29 \pm 1.0$ \\
Non-germinated soybean & $98 \pm 1.8^{* * *}$ & $75 \pm 2.7^{* * *}$ & $88 \pm 2.9$ & $29 \pm 1.0$ \\
Rice straw soybean & $97 \pm 2.3^{* * *}$ & $78 \pm 5.2^{* *}$ & $89 \pm 7.5$ & $31 \pm 4.9$ \\
\hline
\end{tabular}

${ }^{m * *} p<0.01, \quad{ }^{* *} p<0.05$ and ${ }^{*} p<0.1$ are the significance level relative to the control in the same column.
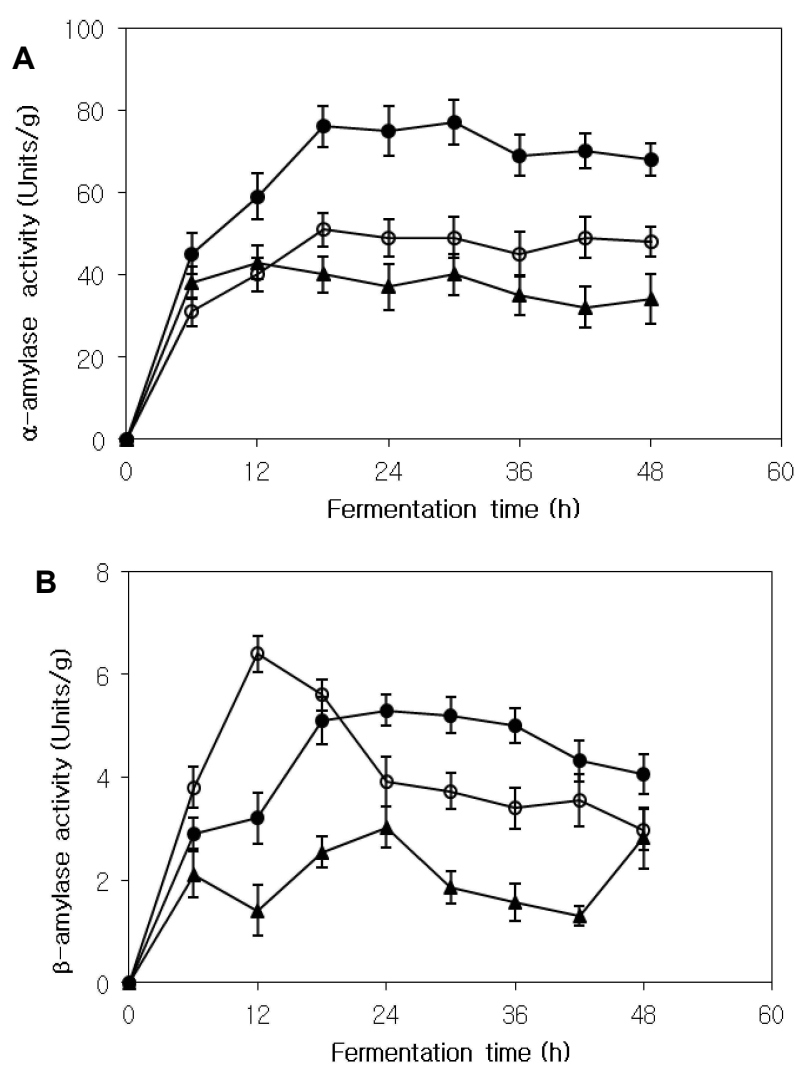

Fig. 7. Changes of amylase activity during Chungkookjang fermentation. (A) a-amylase (B) $\beta$-amylase. Chungkookjang fermented by $B$. subtilis using germinated soybean; $\bigcirc$, Chungkookjang fermented by $B$. subtilis using non-germinated soybean; $\boldsymbol{\Delta}$, Chungkookjang fermented by rice straw using non-germinated soybean.

보여주었다(Fig. 7B). 종균-발아콩은 2.9 5.3 U/g, 종균-미발아 콩은 $3.8 \sim 6.4 \mathrm{U} / \mathrm{g}$, 볏짚-미발아콩은 $1.3 \sim 3.0 \mathrm{U} / \mathrm{g}$ 의 범위에 있 었다. 발효가 진행되면서 amylase 활성이 높게 유지되는 것은 콩에 있는 전분질 원료가 지속적으로 분해된다는 것을 의미하 고, 특히, $\beta$-amylase 활성은 환원당 함량과 비교적 잘 일치하 였다. Oh 등[23]은 볏짚을 접종한 청국장의 $\beta$-amylase 활성은 $3 \sim 11 \mathrm{U} / \mathrm{g}$ 의 범위를 나타내며, $\mathrm{a}$ - 및 $\beta$-amylase 활성은 일정한 경향을 나타내지 않고, 감소한다고 보고하여 본 실험결과와 유사하였다.
청국장이 항산화 효소와 혈청 내 효소의 활성에 미치는 영향 항산화 효소 중 $\mathrm{SOD}$ 는 체내에 생성된 과잉의 활성산화물 을 제거해주는 효소로서 매우 중요하다. 따라서 청국장 추출 물이 마우스 간세포의 SOD 활성에 미치는 영향을 분석하였 고, 그 결과는 Table 2에서 보는 바와 같다. 종균-발아콩, 종균미발아콩 및 볏집-미발아콩은 각각 $100 \%, 98 \%$ 및 $97 \%$ 의 활성 을 나타내어 대조군인 증류수 음용군(71\%)에 비하여 높은 항 산화 활성을 나타내었다.

혈청 내에 존재하는 ALP, AST, ALT는 간세포의 괴사 (necrosis)에 관계하는 중요한 단백질이다. AST, ALT는 아미 노산이나 탄수화물의 대사에 관여하는 효소이며, 다양한 막의 구성성분인 ALP는 막의 glycosylation, 세포의 분화, 세포내 단백질의 합성과 dephosphorylation에 관계한다. 특히 혈액 내 이러한 효소의 증가는 간세포의 괴사나 질병을 나타내는 중요한 지표가 된다. 따라서 청국장이 마우스의 간세포에 미 치는 영향을 분석하기 위해 혈청에서 이들 효소의 활성을 측 정하였으며, 그 결과는 Table 2에서 보는 바와 같다. ALP 활성 은 종균-발아콩의 경우 $66 \%$, 종균-미발아콩의 경우 $75 \%$, 볏짚미발아콩의 경우 $78 \%$ 로 대조군 $(92 \%)$ 에 비해 모든 청국장은 $\mathrm{ALP}$ 의 활성을 감소시킬 수 있었고, 특히 종균-발아콩 $(66 \%)$ 은 $\mathrm{ALP}$ 활성 감소효과가 탁월하였다. 이러한 결과는 실험한 청 국장이 ALP 감소를 통한 간세포의 보호에 매우 우수한 효능 이 있음을 시사하는 것이다. AST 활성의 감소는 종균-발아콩 을 이용한 경우에만 관찰되었고, 종균-미발아콩과 볏짚-미발 아콩에서는 거의 관찰되지 않았다. 또한 모든 청국장은 ALT 활성 감소에 별다른 효과가 없었다. 한편, Kim 등[9]은 당뇨가 유발된 흰쥐에게 청국장 및 된장 분말을 급여한 군에서 혈청 중 ALT, AST 및 ALP 활성이 감소되었다고 하였고, $\operatorname{Lim}$ 등 [21]은 고지혈증 흰쥐에게 비배당체 이소플라본 고함유 대두 분말을 급여한 군에서 ALT 및 AST 활성을 감소시켰다고 보고 하였다. Lee 등[18]은 고콜레스테롤 식이를 섭취한 흰쥐에게 된장 분말을 급이한 결과, 혈청 중 $\mathrm{ALT}, \mathrm{AST}$ 및 $\mathrm{ALP}$ 활성이 감소되었다고 하였다.

\section{감사의 글}

본 연구는 농림수산식품기술기획평가원의 지원에 의하여 수행되었습니다(과제번호 (111030-03). 


\section{References}

1. AOAC. 1990. Official Methods of Analysis. 15th ed. Association of official analytical chemists. Washington, DC.

2. Cho, K. M., Hong, S. Y., Math, R. K., Lee, J. H., Kambiranda, D. M., Kim, J. M., Md. Islam, S. A., Yun, M. G., Cho, J. J., Lim, W. J. and Yun, H. D. 2009. Biotransformation of phenolics (isoflavones, flavanols and phenolic acids) during the Cheonggukjang by Bacillus pumilus HY1. Food Chem 114, 413-419.

3. Eom, S. M., Jung, B. Y. and Oh, H. I. 2009. Changes in chemical components of Cheonggukjang prepared with germinated soybeans during fermentation. J Appl Biol Chem 52, 133-141.

4. Hosoi, T. 1996. Recent progress in treatment of osteroporosis. Nippon Ronen Igakkai Zasshi 33, 240-244.

5. In, J. P. and Lee, S. K. 2004, Effect of yucca (Yucca shidigera) extract on quality characteristics of Chungkookjang using Bacillus subtilis p01. J Korean Soc Appl Bid Chem 47, 176-181.

6. Jeong, W. J., Lee, A. R., Chun, J. Y., Cha, J. H., Song, Y. S. and Kim, J. H. 2009. Properties of Cheonggukjang fermented with Bacillus strains with high fibrinolytic activities. J Food Sci Nutr 14, 252-259.

7. Jung, D. H. and Shim, S. K. 1994. Fermented Soy Foods, pp. 673-686, Spring of Knowledge, Seoul, Korea.

8. Jung, J. B., Choi, S. K., Jeong, D, Y., KIm, Y. S. and Kim, Y. S. 2012. Effects of germination time of soybeans on quality characteristics of Cheonggukjang fermented with an isolated bacterial strain. Korean J Food Sci Technol 44, 69-75.

9. Kim, A. R., Lee, J. J., Cha, S. S., Chang, H. C. and Lee, M. Y. 2012. Effect of soybeans, Chungkukjang, and Doenjang on blood glucose and serum lipid profile in streptozotocin-induced diabetic rats. J Korean Soc Food Sci Nutr 41, 621-629.

10. Kim, J. S. 1996. Current research trends on bioactive function of soybean. Korean Soybean Digest 13, 17-24.

12. Kim, M. H., Lee, N. H. and Choi, U. K. 2008. Fermentation characteristics of Cheonggukjang made of germinated soybean under light condition. J Life Sci 18, 1420-1425.

13. Kim, M. P., Lee, N. H. and Choi, U. K. 2008. Fermentation characteristics of Cheongguljang made of germinated soybean under light condition. J Life Sci 13, 1420-1425.

14. Kim, W., Choi, K., Kim, Y., Park, H., Choi, J., Lee, Y., Oh, H., Kwoon, I. and Lee, S. 1996. Purification and characterization of a fibrinolytic enzyme produced from Bacillus sp. strain CK 11-4 screened from Chungkook-jang. Appl Environ Microbiol 62, 2482-2488.

15. Kim, Y. S., Jung, H. J., Park, Y. S. and Yu, T. S. 2003. Characteristics of flavor and functionality of Bacillus subtilis K-20 Chunggukjang. Korean J Food Sci Technol 35, 475-478.

16. Kwon, H. Y., Ryu, H. Y., Kwon, C. S., Lee, S. H. and Sohn, H. Y. 2007. Optimization of culture conditions of Bacillus pumilus JB-1 for Chungkook-jang fermentation in soybean boiling-waste liquor medium. Korean J Microbiol Biotechnol 35, 304-309.
17. Lee, D. G., Kim, N. Y., Jang, M. K., Yoo, B. H., Kim, K. Y, Kim, S. G., Jeong, Y. K. and Lee, S. H. 2006. Isolation of a fibrinolytic bacterium from Cheongkukjang and characterization of its bioactivity. Korean J Microbiol Biotechnol 34, 299-305.

18. Lee, J. J., Kim, A. R., Lee, H., Kim, C. H., Chang, H. C. and Lee, M. Y. 2010. Effects of powders of soybean and Doenjang on cholesterol level and antioxidant activities in rats fed with a high cholesterol diet. J Life Sci 20, 1134-1142.

19. Lee, J. J., Lee, D. S. and Kim, H. B. 1999. Fermentation patterns of Chungkookjang and Kanjang by Bacillus licheniformis B1. Korean J Microbiol 35, 296-301.

20. Lee, N. R. 2012. Production and functionality of amino acid biomaterial, poly-y-glutamic acid by Bacillus subtilis D7 isolated from Doenjang, a traditional Korean fermented food. M. S. Thesis. Pusan National University, Miryang, Korea.

21. Lim, A. K., Jung, H. K., Hong, J. H., Oh, J. S., Kwak, J. H., Kim, Y. H. and Kim, D. I. 2008. Effects of the soybean powder with rich aglycone isoflavone on lipid metabolism and antioxidative activities in hyperlipidemic rats. J Korean Soc Food Sci Nutr 37, 302-308.

22. Miller, G. L. 1959. Use of dinitrosalicylic acid reagent for determination of reducing sugar. Anal Chem 31, 426-429.

23. Oh, H. I and Eom, S. M. 2008. Changes in microflora and enzyme activities of Cheonggukjang prepared with germinated soybeans during fermentation. Korean $J$ Food Sci Technol 40, 56-62.

24. Park, S. K., Ryu. C. Y. and Lee, S. W. 2008. Establishment of preparation method of Dua-chungkukjang. J Life Sci 18, 1758-1763.

25. Reitman, S. and Frankei, G. 1957. A colorimetric method for the determination of serum glutamic oxaloacetic and glutamic pyruvic transaminase. Am J Clin Pathol 28, 56-63.

26. Shon, M. Y., Kwon, S. H., Park, S. K., Park J. R. and Choi, J. S. 2001. Changes in chemical components of black bean Chungkugjang added with kiwi and radish during fermentation. Korean J Postarvest Sci Technol 8, 449-445.

27. Shon, M. Y., Kwon, S. H., Sung, C. K., Lee, S. W. and Park, S. K. 2001. Isolation and microbiological characteristics of Bacillus megaterium SMY-212 for preparation of black bean Chungkugjang. J Life Sci 11, 304-310.

28. Suh, J. S., Ryu, M. K. and Hur, Y. H. 1983. Effect of Bacillus strains on the Chungkookjang processing III. Changes of the components and enzyme activities during the storage of Chungkookjang. Korean J Food Sci Technol 14, 309-314.

29. Sung, N. J., Ji, Y. A. and Chung, S. Y. 1984. Changes in nitrogenous compounds of soybean during Chungkookjang koii fermentation. J Korean Soc Food Nutr 13, 275-284.

30. Tietze, F. 1969. Enzymatic method for quantitative determination of nanogram amounts of total and oxidized glutathione. Anal Biochem 27, 502-522.

31. Wang, G., Kuan, S. S., Francis, O. J., Ware, G. M. and Carman, A. S. 1990. A simplicated HPLC method for the determination of phytoestrogens in soybean and its processed products. J Agr Food Chem 38, 185-190.

32. Yoo, J. Y. 1997. Present status of industries and research 
activities of Korean fermented soybean products. Microorganism Industry 23, 13-30.

33. Youn, K. C., Kim, D. H., Kim, J. O., Park, B. J., Yook, H. S., Cho, J. M. and Byun, M. W. 2002. Quality characteristics of the Chungkookjang fermented by the mixed culture of Bacillus natto and B. licheniformis. J Korean Soc Food Sci Nutr
31, 204-210.

34. Zhou, J. Y. and Prognon, P. 2006. Raw material enzymatic activity determination: A specific case for validation and comparison of analytical methods-The example of superoxide dismutase (SOD). J Pharm Biomed Anal 40, 1143-1148.

\section{초록 : Bacillus subtilis D7에 의하여 발효된 백태 청국장의 특성}

이나리 ${ }^{1} \cdot$ 박성보 $^{1} \cdot$ 이상미 ${ }^{1}$ · 고태훈 ${ }^{1}$ 황대연 ${ }^{1}$ · 김동섭 ${ }^{1} \cdot$ 정성윤 $^{2} \cdot$ 손홍주 ${ }^{1}$ *

( ${ }^{1}$ 부산대학교 생명자원과학대학, ${ }^{2}$ 대구가톨릭대 의생명과학과)

본 연구에서는 Bacillus subtilis D7과 발아콩을 이용하여 발효된 청국장의 특성을 조사하였다. 백태는 6시간 침 지 후, $25^{\circ} \mathrm{C}$ 에서 2 시간마다 4 일 동안 물을 공급했을 때, 발아율이 가장 높았다. 총 이소플라본 함량은 발아 전 $971.3 \mu \mathrm{g} / \mathrm{g}$ 이었고, 발아 후 $1023.8 \mu \mathrm{g} / \mathrm{g}$ 이었다. 실험에 사용된 모든 청국장에서 아미노태 질소 및 암모니아태 질소 함량은 배양시간이 경과함에 따라 증가하였고, 청국장의 $\mathrm{pH}$ 는 발효과정을 통하여 $\mathrm{pH}$ 7.8-8.0로 증가하였다. 청국장의 생균수는 발효 24 시간까지 급증한 후, 약간 감소하였다. 청국장의 protease 활성은 발효 30-36시간까지 증가하였고, B. subtilis D7를 이용한 청국장의 a- 및 $\beta$-amylase 활성은 발효 12-18시간까지 증가하였다. 청국장을 섭취한 마우스의 ALP 활성과 SOD 활성은 대조군보다 매우 높았다. AST 활성은 미발아콩 청국장 섭취군보다 발아콩 청국장 섭취군에서 더 높았다. 결론적으로 B. subtilis $\mathrm{D} 7$ 을 이용하여 조제된 발아콩 청국장은 품질 특성이 향상되었고, 기능성 성분의 함량이 증가되었다. 